\title{
The stress and trauma of school victimization in Ireland: A retrospective account
}

\author{
Conor Mc Guckin ${ }^{1 *}$, Christopher Alan Lewis ${ }^{2}$, Pauline K. Cummins ${ }^{3}$, \\ and Sharon Mary Cruise ${ }^{4}$ \\ ${ }^{1}$ School of Education, Trinity College Dublin, Dublin 2, Ireland \\ ${ }^{2}$ Division of Psychology, Institute for Health, Medical Science and Society, Glyndŵr University, Wales \\ ${ }^{3}$ School of Arts, Dublin Business School, Dublin 2, Ireland \\ ${ }^{4}$ School of Nursing and Midwifery, Queen's University Belfast, Northern Ireland
}

(Received April 12, 2011; Accepted May 7, 2011)

\begin{abstract}
As part of an international study examining student victimization (by both peers and educators) and posttraumatic stress disorder (PTSD) symptomatology, 154 Irish university students completed the 'Student Alienation and Trauma Scale-Revised'. This examined retrospective accounts of negative experiences in school, identified worst school experiences, and assessed whether an individual developed PTSD symptomatology. Items regarding verbal/relational aggression were reported for both the negative experiences and the worst experience. Whilst $3.1 \%$ of males and $16.3 \%$ of females reported clinically significant PTSD resulting from their worst school experience, a further $3.1 \%$ of males and $3.1 \%$ of females were in the 'at risk' range.
\end{abstract}

Keywords: PTSD symptomatology; stress; trauma; peer-victimization; educator-victimization

Estrés, trauma y victimización escolar en Irlanda: un informe retrospectivo.

RESUMEN: Como parte de un estudio internacional que analiza la victimización en escolares (por parte de otros iguales y de educadores) y la sintomatología del trastorno por estrés postraumático (TEPT), 154 alumnos universitarios completaron la "Escala revisada sobre alienación y trauma en estudiantes". Esta prueba proporciona un informe retrospectivo sobre experiencias negativas en la escuela, identifica las peores experiencias escolares y evalúa si quien responde desarrolló sintomatología asociada a TEPT. Los items relacionados con agresión verbal y relacional aparecieron vinculados tanto a experiencias negativas como a las peores experiencias escolares. El 3.1\% de los hombres y el $16.3 \%$ de las mujeres presentaban TEPT de manera clínicamente significativa como resultado de su peor experiencia en la escuela. El 3.1\% de los hombres y el 3.1\% de las mujeres estaban dentro de una situación de riesgo.

Palabras clave: sintomatología TEPT, estrés, trauma, victimización entre iguales, victimización por educadores 


\section{THE STRESS AND TRAUMA OF SCHOOL VICTIMIZATION IN IRELAND: A RETROSPECTIVE ACCOUNT}

\section{Victimization: The link to impaired health and well-being}

Involvement in bully/victim problems at school has been empirically linked to impaired physical and mental health in major cross-national reviews (e.g., Nansel et al., 2001, 25 countries) and in a meta-analysis of 20 years research (Hawker \& Boulton, 2000). Despite such findings, there is a relative scarcity of research concerning psychological well-being correlates of bullying and victimization (e.g., Kaltiala-Heino, Rimpelä, Rantanen, \& Rimpelä, 2000).

\section{Victimization: The link to PTSD}

The Diagnostic and Statistical Manual for Mental Disorders, Fourth Edition, Text Revision (DSM-IV-TR: American Psychiatric Association [APA], 2000) recognizes that PTSD can develop in childhood. It is only relatively recently that research has attended to the possibility that PTSD may develop from negative school experiences (Hyman \& Snook, 2000). The development of PTSD symptomatology in childhood can severely affect a child's daily functioning, including school performance and fulfilment, and future psychological well-being (Hyman, 1990). Hyman, Cohen, and Mahon (2003) highlight research demonstrating that PTSD during childhood is associated with various disorders, such as: anxiety disorders (Chu \& Dill, 1990), borderline personality disorder (Herman, Perry, \& Van der Kolk, 1989), multiple personality disorder (Kluft, 1985), and conduct disorder (Rogers, 1996). In addition, Hyman, Cohen, and Mahon (2003) report that PTSD has been shown to result in various aberrant behaviours that are 'non-pathological', such as drug use and criminal behaviour (Burgess, Hartman, $\&$ McCormack, 1987). Indeed, the consequences of hostile school environments are reflected in the finding that two-thirds of school shooters felt bullied, threatened, or persecuted prior to carrying out violent acts at school (Vossekull, Fein, Reddy, Borum, \& Madzeleski, 2002; Vossekull, Reddy, Fein, Borum, \& Madzeleski, 2000).

\section{Victimization and PTSD: The evidence}

Mynard, Joseph, and Alexander (2000) assert that there are a number of reasons to believe that an association between peer-victimization and onset of PTSD symptomatology is likely. They argue that the experience of peer-victimization involves a number of important characteristics (e.g., powerlessness, helplessness, poor self-confidence, neuroticism, introversion) which are thought to be involved in the development of posttraumatic stress. Indeed, Hyman, Cohen, Glass et al. (2003) report that severe cases of peer- or educator-victimization might precede and/or be related to the actual onset of PTSD. 
In their study among a sample of UK secondary school pupils who reported having been bullied $(\mathrm{n}=136[\mathrm{~N}=331])$, Mynard et al. (2000) found that $39.8 \%$ $(n=19)$ of the male respondents and $42.6 \%(n=31)$ of the female respondents reported severe levels of PTSD symptoms. Similarly, among a US sample comprising 205 fifth- and sixth-grade students, Storch and Esposito (2003) reported a significant positive relationship between victimization and PTSD symptoms. In his retrospective study, Rivers (2004) found that $17 \%$ of participants who were bullied because of their sexual orientation met the DSM-IV criteria for a diagnosis of PTSD. At a cross-national level (Israel, Greece, US), Hyman, Cohen, Glass et al. (2003) found that between $6 \%$ and $9 \%$ of the students surveyed experienced clinically significant PTSD symptomatology after their worst school experience (there were no significant between-country differences), supporting the notion that the development of PTSD from negative school experiences is a phenomenon that exists across nations within the Western hemisphere.

Hyman, Cohen, and Mahon (2003) consider Student Alienation Syndrome as the result of maltreatment by either peers or educators in a negative school environment. Consisting of three factors (oppositionality, hypervigilance, and hopelessness), Student Alienation Syndrome can be measured by the My Worst Experience Scale (MWES: Hyman, Snook, Berna, DuCette, \& Kohr, 2002) and the Student Alienation and Trauma Survey (SATS: Hyman \& Snook, 2000, 2002). Both scales were derived through factor analysis of a large national sample of school pupils, and are keyed to the DSM-IV-TR (APA, 2000) criteria for the measurement of PTSD (Hyman \& Snook, 2002). The scales function as an assessment tool that (i) identifies which events cause trauma, and (ii) measures the level of the resultant psychological stress/PTSD symptomatology, and indicates the occurrence of Student Alienation Syndrome. The main difference between the MWES (Hyman et al., 2002) and the SATS (Hyman \& Snook, 2000, 2002) is that whilst the former assesses PTSD from any setting, the latter specifically focuses on events that happen within the school setting.

Utilizing the SATS (Hyman \& Snook, 2000, 2002) among a random sample of 196 Greek undergraduate volunteers from various disciplines in a private university (aged mostly over 20 years), Halkias et al. (2003) found that the most common perpetrator of the worst school experience was a teacher, followed by a fellow student (more often a male than a female). Male and female students were equally likely to be victims of a worst school experience, while males were significantly more likely than females to be perpetrators. Males were significantly more likely to be victimized by another male rather than a female, while females were about equally likely to be victimized by either a male or a female. More than half of the respondents reported that they were quite upset from the event, which in almost half the cases occurred between ages of 14 and 17. The most frequently selected worst school experience was 'embarrassment' ( $n=140$, $71.4 \%$ ). The next most frequently selected experiences were: 'I was yelled at' $(n=132,67.3 \%)$, 'I was teased' $(n=126,64.3 \%)$, 'Someone said there was a bomb in the school and we had to leave' $(\mathrm{n}=103,52.6 \%)$. Halkias et al. (2003) note 
that the high reports of bomb threats is reflective of cultural differences between Greece and the US-derived instrument, in that Greek schools routinely receive bomb threats as a type of 'silent student protest' during examination periods. As a group, the sample scored in the 'critical' range of clinical significance (Hyman et al., 2002). Out of the valid total of 137 responses, approximately $3 \%$ met all seven DSM-IV criteria for PTSD (i.e., depression, hopelessness, somatic symptoms, oppositional conduct, hypervigilance, dissociation and dreams, general maladjustment: APA, 2000).

Also utilizing the SATS (Hyman \& Snook, 2000, 2002), Ateah and Cohen (2009) reported data from their cross-national study among 1,217 US and Canadian students $\left(n_{1}=1,007\right.$ college/university students from four universities in the US, $n_{2}=210$ university students from a Canadian university). Overall, the Canadian pupils remembered more victimization in school than their US counterparts. For both country samples, the verbal/relational bullying factor was most often identified as a pupil's very worst school experience (US: 43\%, Canada: $38 \%$ ), thus indicating that these more indirect forms of victimization may have profound long-term mental health effects. Whilst nearly 40\% (US: 37\%, Canadian: $38 \%$ ) reported a different form of abuse (one of the ten other victimization factors), school discipline victimization (US: 15\%, Canada: 17\%) and physical victimization (US: $5 \%$, Canada: 4\%) were also identified as worst school experiences. For both countries, the perpetrator of the very worst school experience was most likely to be male. However, there were significant inter-country differences in that $30.5 \%$ of the perpetrators in the Canadian sample were reported to be adults/school personnel (US: 44\%) and 60.5\% (US: 56\%) were reported to be another pupil $\left(\chi^{2}[1, \mathrm{~N}=944]=10.757, \mathrm{p}=.001\right)$. Adults and/or school personnel were more likely to cause the very worst school experience among the US respondents than in Canada, where other pupils were more often the perpetrator of the very worst school experience. Approximately $8 \%$ of the Canadian sample and $10 \%$ of the US sample met the DSM-IV criteria for a PTSD diagnosis, with almost $.5 \%$ of each sample obtaining clinically significant PTSD T-scores. For both countries, the verbal and relational aggression factor was the type of victimization that most often led to a remembered PTSD diagnosis after a respondent's very worst school experience. Canadian pupils remembered experiencing significantly more oppositional behaviour symptoms after their very worst school experience than their US counterparts $(F[1,1204]=6.731, p=.010)$. However, the effect size was small (partial eta squared=.006). No significant between-participant effects were found in relation to the total PTSD symptomatology subscale, impact of the event, re-experiencing the trauma, avoidance, arousal, depression, oppositionality, hypervigilance, somatization, hopelessness, dissociation, and maladjustment subscales.

In presenting data from a ten-country project that utilized the SATS (Hyman \& Snook, 2000, 2002), Hyman et al. (2004) found strong similarities between the most frequently reported types of victimization: 'I was teased', 'I was yelled at', 'I was embarrassed', and 'I was given detention'. Overall, both male and female 
respondents across most countries reported verbal or relational bullying ('I was teased', 'I was yelled at', 'I was embarrassed', 'Someone got others to not like me') as their worst school experience. Also, both males and females reported that punishment ('I got into trouble because of something I did', 'I was given a punishment that was not fair', 'I was given detention') was their worst school experience. In most countries, males reported that events of a physical nature ('I was in a fight') were their worst school experience.

Respondents were categorized on the SATS (Hyman \& Snook, 2000, 2002) according to their overall PTSD T-scores in the 'clinically significant' range (70T and above), 'at-risk' range (69T to 60T), or 'normal' range (59T or below). Of the total sample in the analysis $(\mathrm{N}=3,267), .7 \%$ of males and $1.3 \%$ of females reported symptoms that met the 'clinically significant' criteria. Nearly $10 \%$ of males $(9.8 \%, n=859)$ and $9.3 \%$ of females $(n=1,432)$ were in the 'at-risk' range. The number of males with PTSD symptomatology did not statistically differ across country. Males who reported some PTSD symptoms ('at-risk') ranged from $3.6 \%$ in the UK to $26.7 \%$ in India. Males who reported clinically significant PTSD symptomatology ranged from $0 \%$ in Canada, the UK, Greece, India, Spain, and Venezuela to $3.7 \%$ in Italy. There was, however, a statistically significant difference in the number of females with PTSD symptomatology among countries $\left(\chi^{2}[18, \mathrm{~N}=1,432]=41.35, \mathrm{p}=.001\right)$. Females in New Zealand $(6.3 \%)$, Venezuela $(1.8 \%)$, Canada $(1.7 \%)$, Greece $(1.7 \%)$, Guatemala $(1.4 \%)$, Spain $(.9 \%)$, and the US $(.6 \%)$ reported severe PTSD symptoms in the clinical range. Females in all countries reported symptoms in the 'at-risk' category, ranging from $1.8 \%$ in Venezuela to $15.2 \%$ in India.

Thus, whilst there is a growing international literature base on the link between retrospective accounts of school victimization and PTSD, no data has been provided, as yet, from Ireland.

\section{The current study}

The present study had three inter-related research questions: (i) how frequently do students in Ireland experience a variety of negative peer- and educator-induced events (e.g., bullying, suspensions)?, (ii) what do pupils in Ireland remember as their worst school experience, and (iii) what percentage of Irish pupils developed PTSD symptomatology post worst school experience?

\section{METHOD}

\section{Respondents}

Respondents were undergraduate students ( $\mathrm{N}=154$ : 64 from Northern Ireland; 90 from the Republic of Ireland) ranging in age from 17 to 55 years (mean 24.18; SD 8.18). There were 27 males (17.5\%) aged 18 to 49 (mean 25.78; SD 9.17) and 127 females (82.5\%) aged 17 to 55 (mean 23.84; SD 7.95). 


\section{Materials}

Respondents completed the Student Alienation and Trauma Survey-Revised (SATS-R: Hyman, Snook et al., 2003), a self-report instrument in two parts. Minor revisions were required in order to make the content of some of the original items relevant to an Irish sample, details of which are available from the first author upon request. Part I comprises a number of demographic questions, as well as 58 items designed to identify the extent to which different types of traumatic events have been experienced by respondents (e.g., Item 1: 'I was teased'; Item 12: 'I was beaten up'). Response options range from 'Did not happen' (0) through 'A few times' (2) to 'All the time' (5). Additionally, two columns to the right of the response option for each of the 58 items allow the respondent to indicate whether the perpetrator of the negative event was either 'Another student' or a 'Teacher or another educator'.

After completion of Part I, respondents are asked to circle their single worst experience from the 58 listed, and to provide more information about their single worst experience, as follows: who best describes the perpetrator of their single worst experience (e.g., 'teacher', 'caretaker', 'student'); sex of perpetrator; age of participant at the time the event occurred; grade the participant was in at school when it happened; did their worst experience take place in the same country where they were currently attending university (or not); the extent to which the event affected them; and the type of school (e.g., public or private) they were attending when it happened. Respondents are then asked to describe their single worst experience.

Part II is derived from its parent form, the Student Alienation and Trauma Survey (SATS: Hyman \& Snook, 2000, 2002), which in turn is derived from the My Worst Experience Scale (MWES; Hyman et al., 2002), a scale which boasts robust internal consistency (total scale $\alpha=.97$; Hyman et al., 2002) and test-retest reliability ( $\alpha=.95$ over six weeks; Berna, 1993). Part II of the SATS-R comprises a list of 105 symptoms assessing posttraumatic stress disorder (PTSD) symptomatology. Respondents indicate the frequency of each symptom, specifically in relation to their single worst experience (as identified in Part I). Response options range from 'Did not happen' (0) through 'A few times' (2) to 'All the time' (5). A total summated score on 102 of the 105 symptoms (Items 8, 65, and 71 are excluded) provides a global measure of stress symptoms. Four subscales derived from 57 of the 105 items may be used to assess DSM-IV-TR (APA, 2000) criteria for PTSD. Additionally, it is possible to establish the presence of distress in seven specific symptom areas. However, analysis within the present research focused on the total score of the MWES. Additionally, one column to the right of the response option for each item allowed the participant to indicate if the duration of the victimization 'Lasted for more than one month'. The total MWES score categorized respondents into one of three groups. This categorisation was similar to the SATS (Hyman \& Snook, 2000, 2002), where respondents were categorized according to their overall PTSD T-scores in the 'clinically significant' range 
(70T and above), 'at-risk' range (69T to 60T), or 'normal' range (59T or below). However, in the case of MWES, instead of using T-scores, this was completed by using the conversion tables to calculate the appropriate ranges for the overall scores. As a result, the following was used as the ranges for categorization: 'clinically significant' range (254 and above), 'at-risk' range (141 to 253), and 'normal' range (140 or below).

\section{Procedure}

The study was verbally explained to respondents, including issues relating to voluntary participation, anonymity, and confidentiality. Consent forms and a list of professional support agencies, were also given to respondents.

Owing to the sensitive nature of the topic, and the fact that completion required a great deal of retrospection, respondents were instructed to take the questionnaire pack home for private completion in their own time.

\section{RESULTS}

\section{Research question 1}

The frequencies of the ten most commonly reported negative events from Part 1 of the SATS-R are presented in Table 1.

Table 1. Summary Of The Ten Most Commonly Experienced Negative School Events In Northern Ireland And The Republic Of Ireland

\begin{tabular}{|l|c|c|c|c|}
\hline Item & N & Mean* & SD & $\begin{array}{c}\text { \% } \\
\text { Bullied** }\end{array}$ \\
\hline I was embarrassed & 153 & 2.65 & 1.18 & 24.2 \\
\hline I was teased & 152 & 2.46 & 1.26 & 25.6 \\
\hline I was yelled at & 151 & 2.10 & 1.13 & 9.3 \\
\hline I was picked last & 151 & 1.49 & 1.57 & 14.6 \\
\hline I was left out & 151 & 1.49 & 1.49 & 13.9 \\
\hline Other students stopped talking to me & 152 & 1.32 & 1.34 & 7.2 \\
\hline $\begin{array}{l}\text { I got into trouble because of something I } \\
\text { did }\end{array}$ & 152 & 1.22 & 1.23 & 4.6 \\
\hline Someone got others to not like me & 152 & 1.22 & 1.42 & 11.2 \\
\hline Someone made up a story about me & 150 & 1.19 & 1.27 & 6.0 \\
\hline $\begin{array}{l}\text { Someone picked on me on my way to or } \\
\text { from school. }\end{array}$ & 152 & 1.11 & 1.45 & 9.9 \\
\hline
\end{tabular}

* $0=$ did not happen; $1=$ one time; $2=$ a few times; $3=$ more than a few times; $4=\mathrm{a}$ lot; $5=$ all the time

** \% Bullied indicates respondents who specified 4 or 5 for frequency 
As can be seen in Table 1, 'I was embarrassed' (Item 3) was reported as the most commonly experienced negative school event, followed by 'I was teased' (Item 1) and 'I was yelled at' (Item 2). The average for each of these items fell between the response options of a 'few times' and 'more than a few times.' Table 1 also shows the percentage of respondents who reported being a victim of bully/victim problems. In order to distinguish bullying behaviour from the other forms of victimization, specific criteria had to be met for it to be inferred. If the respondent reported that the traumatic event happened 'a lot' or 'all of the time', bullying was concluded. Based on this, it can be seen that in relation to the item 'I was teased' (Item 1), 25.6\% $(n=39)$ of respondents reported that they experienced this to the extent that it was considered bullying behaviour. Similar percentages were reported for the 'I was embarrassed' (Item 3) item, with 24.2\% $(n=37)$ being deemed bullying.

\section{Research question 2}

Table 2. Summary Of The Single Worst Experience Remembered By Males

\begin{tabular}{|l|c|}
\hline Item & $\begin{array}{c}\text { Percent } \\
\text { Males }\end{array}$ \\
\hline I was embarrassed & 13.0 \\
\hline I was beaten up & 13.0 \\
\hline Someone made up a story about me & 13.0 \\
\hline $\begin{array}{l}\text { Someone threatened to do something bad to me or to someone I } \\
\text { care about }\end{array}$ & 8.7 \\
\hline I was teased & 4.3 \\
\hline I was yelled at & 4.3 \\
\hline I was not allowed to be part of special subjects or activities & 4.3 \\
\hline Things like a book, eraser, or something else, were thrown at me & 4.3 \\
\hline I was made to stay alone, away from everybody & 4.3 \\
\hline I was punched & 4.3 \\
\hline
\end{tabular}

As can been seen in Table 2, 'I was embarrassed' (Item 3), 'I was beaten up' (Item 12), and 'Someone made up a story about me' (Item 40) were top three single worst school experience for males, with each being reported by $13 \%(n=3)$ of male respondents. 
Table 3: Summary of Single Worst School Experience for Northern Ireland and Republic of Ireland for Females

\begin{tabular}{|l|c|}
\hline Item & $\begin{array}{c}\text { Percent } \\
\text { Females }\end{array}$ \\
\hline I was embarrassed & 12.3 \\
\hline I was teased & 11.4 \\
\hline I was left out & 7.9 \\
\hline Someone picked on me on my way to or from school & 7.0 \\
\hline Other & 6.1 \\
\hline Other students stopped talking to me & 5.3 \\
\hline Someone killed him or herself & 5.3 \\
\hline I was touched sexually & 3.5 \\
\hline Someone said bad things about my mother or family & 3.5 \\
\hline I was slapped & 2.6 \\
\hline
\end{tabular}

As can been seen in Table 3, 'I was embarrassed' (Item 3) was the most frequently reported worst experience, with $12.3 \%(\mathrm{n}=14)$ for females, followed by 'I was teased' (Item 1: 11.4\%, n=13) and 'I was left out' (Item 38: 7.9\%, n=9).

\section{Research question 3}

In relation to the development of PTSD symptomatology post the worst school experience, respondents were categorized according to their overall PTSD T-scores. Although 74.4\% $(\mathrm{n}=96)$ of respondents fell within the 'normal' range, $19.4 \%(n=25)$ were assigned to the 'at-risk' range, and $6.2 \%(n=8)$ of respondents fell into the 'clinically significant' range. No significant sex differences existed $\left(\chi^{2}(2)=4.814, \mathrm{p}>.05\right)$.

\section{DISCUSSION}

The most commonly reported negative events were in relation to verbal/relational aggression (e.g., being teased, being left out), with Item 3, 'I was embarrassed', being the most commonly reported negative event. This is consistent with previous research using the same methodology (e.g., Hyman et al., 2004). The percentage of respondents satisfying the criteria to have been bullied across the ten most commonly selected events ranged from $4.6 \%$ to $25.6 \%$.

Interestingly, with regard to the second aim, Item 3, 'I was embarrassed', was also reported as being the single worst experience for both males and females, thus indicating that verbal/relational aggression may have profound long-term 
mental health effects. Again, this finding mirrors that from Hyman et al.'s (2004) ten country study, where items involving verbal/relational aggression were reported as the worst experience.

Whilst nearly one-fifth of the respondents were in the 'at risk' category regarding PTSD symptomatology $(19.4 \%, \mathrm{n}=25), 6.2 \%(\mathrm{n}=8)$ were in the 'clinically significant' category, highlighting the significant relationship between school victimization and impaired health and well-being. However, a word of caution is required here in terms of interpreting these results. As noted previously, whilst the instrument used in the research was derived through factor analysis of a large national sample of school pupils, and are keyed to the DSM-IV-TR (APA, 2000) criteria for the measurement of PTSD (Hyman \& Snook, 2002), it is important to emphasise here the crucial distinction between assessments of PTSD symptomatology and clinical diagnosis of PTSD. Thus, whilst not a diagnostic instrument in itself, future research and applied practice may wish to consider its use as a screening instrument, to be used together with clinical interviews and / or medical examinations to detect posttraumatic stress disorders.

The current research provides further support for Hyman et al.'s (2004) contention that highly negative events occurring in the school environment may lead to Student Alienation Syndrome (defined by symptoms of hopelessness, oppositionality, and hypervigilance) and PTSD symptomatology. This research also provides further psychometric support for the usefulness of the SAT-R to measure the effects of pupil victimization by peers and teachers among a sample of students in Ireland.

In terms of methodological issues, the study, as with previous work in the area, was retrospective. However, such a design did negate the logistical and ethical issues inherent in obtaining parental permission and providing follow-up counselling and support services for a school-based sample. Such an approach would have been unnecessarily prohibitive.

Whilst there may indeed be a relationship between experience of school victimization and PTSD symptomatology, given the methodology employed in the study, the causal relationship between these variables is cannot be established. For example, does victimization serve to erode the health and well-being of the individual, or are the victims of bullies picked on because they are more vulnerable in the first place? Whilst most research in this area has been cross-sectional in nature, only longitudinal research designs can fully answer such a question. As an example of the insight that such longitudinal research could yield, studies in the area of peer-peer bully/victim problems have demonstrated the former of these propositions, in that victimization does have adverse effects on the health and well-being of pupils (Egan \& Perry, 1998; Kochenderfer \& Ladd, 1996; Olweus, 1992; Rigby, 1999).

Further muddying the issue is that all variables of interest here may be acting in a 'vicious cycle' (Salmivalli, Karhunen, \& Lagerspetz, 1996). Accordingly, it could be that the pupil's behaviour and/or reduced levels of health and well-being may predispose the pupil to being a potential target of bullying behaviours (e.g., 
Hodges \& Perry, 1999), and that subsequent victimization directed towards them could reinforce and perpetuate their difficulties, making the individual more of a target for bullying behaviours from the same and/or different bullies (Swearer, Song, Cary, Eagle, \& Mickelson, 2001).

Future research efforts should also extend beyond the methodological rigour of sophisticated longitudinal designs to allow for an understanding of what happens to those children who are victimized and develop PTSD symptomatology. Indeed, of concern also is the future health and well-being of those victims who are never correctly diagnosed and go on to develop problems involving their physical, psychological, and social development (Halkias et al., 2003). Adjustments to the pre-service training of teachers may be required so as to enable these professionals to identify the early signs of victimization and the remedies available to deal with such insidious behaviours. Indeed, without such training, teachers may be managing such issues, albeit subconsciously, based upon their own retrospective experiences of school victimization (Cummins, Mc Guckin, \& Lewis, 2009; Halkias et al., 2003).

In conclusion, victimization by peers and/or educators can have major and long lasting negative effects. In line with the international efforts to understand the nature, incidence, correlates, and prevention of such insidious behaviours, attention also needs to be directed towards the immediate and long-term health and well-being consequences of such victimization.

\section{REFERENCES}

American Psychiatric Association. (2000). Diagnostic and statistical manual of mental disorders, Fourth Edition, Text Revision. Washington, DC: American Psychiatric Association

Ateah, C., \& Cohen, I. (2009). School victimization and bullying experiences: Cross-national comparisons between Canada and the United States. Currents: New Scholarships in the Human Services, 8, 1-17.

Burgess, A. W., Hartman, C. R., \& McCormack, A. (1987). Abused to abuser: Antecedents of socially deviant behaviors. American Journal of Psychiatry, 141, 1431-1436.

Chu, J. A., \& Dill, D. L. (1990). Dissociative symptoms in relation to childhood physical and sexual abuse. American Journal of Psychiatry, 147, 887-892.

Cummins, P., Mc Guckin, C., \& Lewis, C. A. (2009). What do they know? Trainee teachers' knowledge and attitudes of bully/victim problems in schools. Conference paper presented at The Psychological Society of Ireland Annual Conference, Whites Hotel, Wexford, Co. Wexford, Republic of Ireland, 5-8th November, 2009.

Egan, S. K., \& Perry, D. G. (1998). Does low self-regard invite victimization? Developmental Psychology, 34, 299-309.

Halkias, D., Fakinos, M., Hyman, I., Cohen, I., Akrivos, D., \& Mahon, M. (2003). Victimization of children in Greek schools: Stress and trauma symptoms rela- 
ted to school bullying. Paper presented at the 9th Panhellenic Conference on Psychological Research, Rhodes, Greece, May 21, 2003.

Hawker, D. S. J., \& Boulton, M. J. (2000). Twenty years' research on peer victimization and psychosocial maladjustment: A meta-analytic review of crosssectional studies. Journal of Child Psychology and Psychiatry, 41, 441-455.

Herman, J. L., Perry, J. C., \& Van der Kolk, B. A. (1989). Childhood trauma in borderline personality disorder. American Journal of Psychiatry, 146, 490495.

Hodges, E. V. E., \& Perry, D. G. (1999). Personal and interpersonal antecedents and consequences of victimization by peers. Journal of Personality and Social Psychology, 76, 677-685.

Hyman, I. (1990). Reading, writing, and the hickory stick: The appalling story of physical and psychological abuse in American schools. Lexington, IL: Lexington Books.

Hyman, I., Cohen, I., Glass, J., Kay, B., Mahon, M., Siegel, N., Tabori, A., \& Weber, M. (2003, June). School bullying: Theory, research, assessment, and interventions. Workshop presented at the Annual Convention of the Pennsylvania Psychological Association, Harrisburg, PA.

Hyman, I., Cohen, I., \& Mahon, M. (2003). Student Alienation Syndrome: A paradigm for understanding the relation between school trauma and school violence. The California School Psychologist, 8, 73-86.

Hyman, I., Cohen, I., Mahon, M., Tabori, A., Ateah, C., Báguena, J. et al. (2004). Bullying and victimization in the schools: A preliminary analysis of a cross national study. Paper presented as part of poster session, "Bullying and victimization in the schools: A preliminary analysis cross national study", at the American Psychological Association Conference, July 30th, 2004, Honolulu, HI.

Hyman, I., \& Snook, P. (2000, August). Student alienation syndrome: Theory, assessment and application. Paper presented at the 108th National Convention of the American Psychological Association, Washington, DC.

Hyman, I., \& Snook, P. (2002). Manual for the My Worst Experience Scale (MWES). Los Angeles: Western Psychological Services.

Hyman, I., Snook, P., Berna, J., DuCette, J., \& Kohr, M. (2002). Manual for the My Worst Experience Scales (MWES). Los Angeles: Western Psychological Services.

Hyman, I. A., Snook, P. A., Berna, J. M., Kohr, M. A., DuCette, J. P., Cohen, I., \& Mahon, M. (2003). Student Alienation and Trauma Survey-Revised. Los Angeles: Western Psychological Services.

Kaltiala-Heino, R., Rimpelä, M., Rantanen, P., \& Rimpelä, A. (2000). Bullying at school - an indicator of adolescents at risk for mental disorders. Journal of Adolescence, 23, 661-674.

Kluft, R. P. (1985). Childhood antecedents of multiple personality. Washington, DC: American Psychiatric Press.

Kochenderfer, B. J., \& Ladd, G. W. (1996). Peer victimisation: Cause or conse- 
quence of school maladjustment. Child Development, 67, 1305-1317.

Mynard, H., Joseph, S., \& Alexander, J. (2000). Peer-victimization and posttraumatic stress in adolescents. Personality and Individual Differences, 29, 815-821.

Nansel, T. R., Overpeck, M., Pilla, R., Ruan, W. J., Simons-Morton, B., \& Scheidt, P. (2001). Bullying behaviours among US youth: Prevalence and association with psychosocial adjustment. Journal of the American Medical Association, 285, 2094-2100.

Olweus, D. (1992). Victimisation by peers: Antecedents and long-term outcomes. In K. H. Rubin \& J. B. Asendorf (Eds.), Social withdrawal, inhibition and shyness in children (pp. 315-341). Hillsdale, NJ: Erlbaum.

Rigby, K. (1999). Peer victimisation at school and the health of secondary school students. British Journal of Educational Psychology, 69, 95-104.

Rivers, I. (2004). Recollections of bullying at school and their long-term implications for lesbians, gay men, and bisexuals. The Journal of Crisis Intervention and Suicide Prevention, 25, 169-175.

Rogers, K. L. (1996). Posttraumatic stress disorder in a sample of conduct disordered youth. Dissertation Abstracts International, Section B: The Sciences \& Engineering, 57(12-B), 2163.

Salmivalli, C., Karhunen, J., \& Lagerspetz, K. M. J. (1996). How do the victims respond to bullying? Aggressive Behavior, 22, 99-109.

Smith, P. K. (Ed.) (2003). Violence in schools. The response in Europe. London: RoutledgeFalmer.

Storch, E. A., \& Esposito, L. E. (2003). Peer victimization and posttraumatic stress among children. Child Study Journal, 33, 91-98.

Swearer, S. M., Song, S. Y., Cary, P. T., Eagle, J. W., \& Mickelson, W. T. (2001). Psychosocial correlates in bullying and victimization: The relationship between depression, anxiety, and bully/victim status. Co-published simultaneously in Journal of Emotional Abuse, 2, 95-121; and in R. A. Geffner, M. Loring, \& C. Young (Eds.), Bullying behaviour: Current issues, research, and interventions (pp. 95-121). New York: The Haworth Maltreatment \& Trauma Press.

Vossekull, B., Fein, R. Z., Reddy, M., Borum, R., \& Madzeleski, W. (2002). The final report and findings of the Safe School Initiative: Implications for the prevention of school attacks in the United States. Washington, DC: US Secret Service and US Department of Education.

Vossekull, B., Reddy, M., Fein, R., Borum, R., \& Madzeleski, W. (2000). Safe school initiative: An interim report on the prevention of targeted violence in schools. US Secret Service National Threat Assessment Center. http://www. ustrea.gov/usss/ntac_ssi_report.pdf. (Retrieved 13 July 2009) 